\title{
Monoamine Oxidase and Semicarbazide-Sensitive Amine Oxidase Kinetic Analysis in Mesenteric Arteries of Patients With Type 2 Diabetes
}

\author{
S. F. NUNES ${ }^{1}$, I. V. FIGUEIREDO ${ }^{1,3}$, J. S. PEREIRA ${ }^{2}$, E. T. DE LEMOS $^{3}$, F. REIS ${ }^{3}$, \\ F. TEIXEIRA ${ }^{3}$, M. M. CARAMONA ${ }^{1}$
}

${ }^{1}$ Laboratory of Pharmacology, Faculty of Pharmacy, Coimbra University, Coimbra, Portugal,

${ }^{2}$ Portuguese Oncology Institute of Coimbra, Portugal, ${ }^{3}$ Institute of Pharmacology and Experimental Therapeutics, IBILI, Faculty of Medicine, Coimbra University, Coimbra, Portugal

Received February 22, 2010

Accepted August 30, 2010

On-line November 29, 2010

\begin{abstract}
Summary
Monoamine oxidase (MAO, type $\mathrm{A}$ and $\mathrm{B}$ ) and semicarbazidesensitive amine oxidase (SSAO) metabolize biogenic amines, however, the impact of these enzymes in arteries from patients with type 2 diabetes remains poorly understood. We investigated the kinetic parameters of the enzymes to establish putative correlations with noradrenaline (NA) content and patient age in human mesenteric arteries from type 2 diabetic patients. The kinetic parameters were evaluated by radiochemical assay and NA content by high-performance liquid chromatography (HPLC). The activity of MAO-A and SSAO in type 2 diabetic vascular tissues was significantly lower compared to the activity obtained in non-diabetic tissues. In the correlation between MAO-A $\left(K_{\mathrm{m}}\right)$ and NA content, we found a positive correlation for both the diabetic and non-diabetic group, but no correlation was established for patient age. In both groups, MAO-B ( $\left.V_{\max }\right)$ showed a negative correlation with age. The results show that MAO-A and SSAO activities and NA content of type 2 diabetic tissues are lower compared to the non-diabetic tissues, while MAO-B activity remained unchanged. These remarks suggest that MAO-A and SSAO may play an important role in vascular tissue as well as in the vascular pathophysiology of type 2 diabetes.
\end{abstract}

\section{Key words}

Human mesenteric arteries - Monoamine oxidase • Semicarbazide-sensitive amine oxidase - Type 2 diabetes • Noradrenaline content

\section{Corresponding author}

M. M. Caramona, Laboratory of Pharmacology, Faculty of Pharmacy, Coimbra University, 3000-548, Coimbra, Portugal. Fax: +351 239488 503. E-mail: magui@ff.uc.pt

\section{Introduction}

Oxidative stress can be defined as a disturbance in the balance between the production of free radicals such as superoxide anion, hydroxyl radicals and hydrogen peroxide - and antioxidant mechanisms (Ramakrishna and Jailkhani 2008). These pathways also include monoamine oxidases (A and $\mathrm{B}$ ) and semicarbazidesensitive amine oxidase (SSAO) enzymes which take part in pathological changes, such as cardiac diseases and diabetic complications (Bianchi et al. 2005, Obata 2006).

Monoamine oxidase (MAO, EC 1.4.3.4) catalyzes the oxidative deamination of biogenic amines (adrenaline, noradrenaline, serotonin, dopamine, tyramine and tryptamine) to the corresponding aldehyde, hydrogen peroxide $\left(\mathrm{H}_{2} \mathrm{O}_{2}\right)$ and ammonia (Nagatsu 2004). In vitro, serotonin and noradrenaline (NA) are the preferential MAO-A substrates and the MAO-A enzyme is inhibited by clorgyline, whereas $\beta$-phenylethylamine is a substrate for MAO-B and selegiline as a selective MAO-B inhibitor. MAO (type $\mathrm{A}$ and $\mathrm{B}$ ) functions include catabolism of exogenous amines, regulation of neurotransmitter levels and control of intracellular amine 
stores. Thus, it might be expected that their distribution in central nervous system and in other tissues is a reflection of these physiological roles (Billett 2004).

The semicarbazide-sensitive amine oxidase enzyme (SSAO, EC 1.4.3.6) catalyzes the oxidative deamination of primary amines, such as methylamine or aminoacetone, to produce the corresponding aldehyde (formaldehyde and methylglyoxal, respectively) and converts circulating aliphatic and aromatic amines (tyramine, tryptamine, histamine and dopamine) into the corresponding aldehyde, $\mathrm{H}_{2} \mathrm{O}_{2}$ and ammonia, but is relatively inactive for NA and serotonin (Elliott et al. 1989, Obata 2006). The SSAO enzyme is present in blood, associated with cell membranes, such as endothelial and smooth muscle cells of blood vessels, and is selectively inhibited by semicarbazide (del Mar Hernandez et al. 2005). This enzyme is also known as vascular adhesion protein-1 (VAP-1) and plays an important role in the adhesion and migration of leukocytes to sites of inflammation (Bour et al. 2009).

The mesenteric innervation system plays an important role in controlling mesenteric capacitance, and there are some studies reporting MAO (type A and B) and SSAO activity in non-diabetic patients (Figueiredo et al. 1998, Birch et al. 2008). However, the impact of those enzymes in the inferior mesenteric arteries of patients with type 2 diabetes remains poorly understood. The present study aims to determine $\left(K_{\mathrm{m}}\right)$ and $\left(V_{\max }\right)$ for the three enzymes, as well as to determine the NA content in inferior mesenteric arteries, in order to establish correlations between MAO-A and MAO-B with NA content, and also between MAO enzymes and patient age. A putative correlation can help to understand the influence of MAO and SSAO enzymes in the pathophysiological damage in the arterial walls from patients with type 2 diabetes.

\section{Materials and Methods}

\section{Study population}

Segments of human inferior mesenteric arteries from 12 non-diabetic patients (average age: 62.2 \pm 10.9 years old, 7 men and 5 women) and 8 patients with type 2 diabetes (average age: 63.1 \pm 6.2 years old, 5 men and 3 women), obtained from patients submitted for colorectal surgery, were provided by the Surgery Department of the Portuguese Oncology Institute of Coimbra. The study was approved by local medical ethics committee following the rules from Declaration of
Helsinki of the World Medical Association, and all participants provided informed consent. Only nonsmokers participated in the study, and none of the participants suffered from thyroid dysfunction or liver disorders.

The population included in this study consisted of patients with sigmoid or rectum carcinoma who were not subject to neo-adjuvant therapeutics and who presented surgery as the primary option. The type of surgical intervention used depended on the location of the tumor and whether sigmoidectomy or anterior recession of the rectum was carried out. The non-diabetic patients were selected according to the following criteria: blood glucose concentrations $<110 \mathrm{mg} / \mathrm{dl}$, not suffering from hypertension or renal disease (serum creatinine $<1.20 \mathrm{mg} / \mathrm{dl}$ ). The group with type 2 diabetes was chosen with blood glucose concentrations $>110 \mathrm{mg} / \mathrm{dl}$, with $\mathrm{HbA}_{1 \mathrm{c}}>6 \%$ and on treatment with an oral antidiabetic drug. Vessels of greatest calibre (namely the inferior mesenteric artery) were selected as study material; in order to avoid interference from pathological anatomy. Only macroscopically healthy vessels were used.

The arteries were placed in cold physiological saline solution and immediately transported to the laboratory where $\pm 200 \mathrm{mg}$ of each artery were homogenized 1:10 (w/v) with a concentric glass homogenizer in $10 \mathrm{mM}$ sodium phosphate buffer (pH 7.4) at $4{ }^{\circ} \mathrm{C}$ and the supernatant from the $600 \mathrm{~g}$ spin was taken and stored at $-80{ }^{\circ} \mathrm{C}$ until further analysis.

Determination of MAO (A and B) and SSAO in the vascular tissues

MAO (A and B) and SSAO activities were determined by radiochemical methods using ${ }^{3} \mathrm{H}-5-$ hydroxytryptamine creatinine sulphate $\left({ }^{3} \mathrm{H}-5-\mathrm{HT}\right)$, in a concentration range between 50-1 $000 \mu \mathrm{M}$ for MAO-A, ${ }^{14} \mathrm{C}-\beta$-phenylethylamine hydrochloride $\left({ }^{14} \mathrm{C}-\beta\right.$-PEA $)$, 5-160 $\mu \mathrm{M}$ for MAO-B and ${ }^{14} \mathrm{C}$-benzylamine $\left({ }^{14} \mathrm{C}\right.$-BZ $)$, in a concentration range 50-1 $600 \mu \mathrm{M}$ for $\mathrm{SSAO}$ (Figueiredo et al. 1998). 5-HT, $\beta$-PEA and BZ were purchased from Sigma-Aldrich (Madrid, Spain), ${ }^{3} \mathrm{H}-5-\mathrm{HT}$ (15.1 Ci/mmol) and ${ }^{14} \mathrm{C}-\mathrm{BZ} \quad(54 \mathrm{mCi} / \mathrm{mmol})$ from Amersham International (London, United Kingdom) and ${ }^{14} \mathrm{C}$ - $\beta$-PEA (43.8 $\mathrm{mCi} / \mathrm{mmol}$ ) from Perkin Elmer LAS (Boston, MA). The MAO inhibitors and all other reagents used were of analytical grade.

The tissue homogenates $(25 \mu \mathrm{l})$ were preincubated for $20 \mathrm{~min}$, at $37^{\circ} \mathrm{C}$, with selegiline $\left(10^{-4} \mathrm{M}\right)$ as MAO-B inhibitor or clorgyline $\left(10^{-6} \mathrm{M}\right)$ as MAO-A 
Table 1. MAO-A, MAO-B and SSAO kinetic parameters in mesenteric arteries homogenates of non-diabetic group and patients with type 2 diabetes.

\begin{tabular}{llcc}
\hline & & $\begin{array}{c}\text { Non-diabetic group } \\
(\mathbf{n = 1 2})\end{array}$ & $\begin{array}{c}\text { Type 2 diabetic group } \\
(\mathbf{n}=\mathbf{8})\end{array}$ \\
\hline \multirow{2}{*}{ MAO-A } & $V_{\max }\left(\mathrm{nmol} . \mathrm{mg} \operatorname{protein}^{-1} \cdot \mathrm{h}^{-1}\right)$ & $60.06 \pm 21.43$ & $32.13 \pm 18.24^{*}$ \\
& $K_{\mathrm{m}}(\mu \mathrm{M})$ & $178.30 \pm 99.17$ & $200.90 \pm 122.60$ \\
\multirow{2}{*}{ MAO-B $B$} & $V_{\max }\left(\mathrm{nmol.mg} \operatorname{protein}^{-1} \cdot \mathrm{h}^{-1}\right)$ & $15.20 \pm 3.03$ & $12.31 \pm 6.87$ \\
& $K_{\mathrm{m}}(\mu \mathrm{M})$ & $100.50 \pm 38.87$ & $100.40 \pm 59.68$ \\
\multirow{3}{*}{ SSAO } & $V_{\max }\left(\mathrm{nmol} . \mathrm{mg} \operatorname{protein}^{-1} \cdot \mathrm{h}^{-1}\right)$ & $229.10 \pm 46.28$ & $148.30 \pm 39.11^{*}$ \\
& $K_{\mathrm{m}}(\mu \mathrm{M})$ & $301.00 \pm 127.30$ & $228.10 \pm 134.30$ \\
\hline
\end{tabular}

Values are means \pm S.D. $* P<0.05$ (Mann-Whitney test).

inhibitor. Increasing concentrations of the corresponding radioactive substrates $(50 \mu \mathrm{l})$ were added and the solution was oxygenated. After incubation for $20 \mathrm{~min}$ at $37^{\circ} \mathrm{C}$, the reaction was stopped by the addition of $10 \mu \mathrm{HCl}$ ( $3 \mathrm{~mol} / \mathrm{l})$. The deaminated products were then extracted with ethyl acetate $(400 \mu \mathrm{l})$ followed by centrifugation at $3000 \mathrm{~g}$. The resulting supernatant $(200 \mu \mathrm{l}$ aliquot) was transferred to counting vials with scintillation fluid $(6 \mathrm{ml})$ for radiochemical measurements.

The SSAO activity was determined as described for MAO using clorgyline $\left(10^{-6} \mathrm{M}\right)$ and selegiline $\left(10^{-4} \mathrm{M}\right)$ as inhibitors with 20 min pre-incubation times. The final incubation with ${ }^{14} \mathrm{C}$-benzylamine hydrochloride was $5 \mathrm{~min}$. The radioactivity released from the mixtures was measured in a Packard 2000 Tri-Carb liquid scintillation counter (Canberra, Australia) and calculations were performed to express MAO (A and B) and SSAO activities in nanomoles of substrate metabolised per $\mathrm{mg}$ of protein per hour (nmol.mg protein $\left.^{-1} \cdot h^{-1}\right)$. Protein content in the homogenates was determined by Lowry method (Lowry et al. 1951).

\section{NA assay}

The NA content in the arteries was determined by high-performance liquid chromatography (HPLC) with electrochemical detection. The small mesenteric artery segments were placed in perchloric acid $(0.1 \mathrm{M}$, Merck) at $4{ }^{\circ} \mathrm{C}$ for $24 \mathrm{~h}$. The NA content was measured using known NA standard (Sigma Chemical Co.) concentrations and chromatograms were obtained using the appropriate HPLC software (Reis et al. 2005). NA concentrations were expressed in $\mu \mathrm{g} / \mathrm{g}$ wet tissue.

\section{Statistical analysis}

The results were expressed as mean values \pm standard deviation (S.D.). The results from kinetic studies were plotted by a computer-generated Hanes-Woolf plots using linear regression to obtain apparent $\mathrm{K}_{\mathrm{m}}$ and $\mathrm{V}_{\max }$ values. Statistical evaluation between the groups was performed by the non-parametric Mann-Whitney test. Pearson correlation and multiple regression analysis were used to test the correlations. The statistics were performed using commercial Graph Pad Prism software version 4.0 (San Diego, CA, USA) and Analysis ToolPak added to Microsoft Office Excel $2007^{\circledR}$. Statistical significance was considered for $\mathrm{P}<0.05$.

\section{Results}

\section{MAO (type $A$ and $B$ ) and SSAO activities}

Table 1 summarises the results obtained from experiments to MAO (A and B) and SSAO kinetics parameters in homogenates of inferior mesenteric arteries. The $\mathrm{K}_{\mathrm{m}}$ values were unchanged in MAO-A $(178.30 \pm 99.17 \mu \mathrm{M}$ vs. $200.90 \pm 122.60 \mu \mathrm{M}, \mathrm{P}>0.05)$ and MAO-B $(100.50 \pm 38.87 \mu \mathrm{M}$ vs. $100.40 \pm 59.68 \mu \mathrm{M}$, $\mathrm{P}>0.05$ ) for both, non-diabetic and type 2 diabetic tissues, respectively. The MAO-A $\left(\mathrm{V}_{\max }\right)$ results in the mesenteric arteries from patients with type 2 diabetes $(n=8)$ showed significant lower values compared to the non-diabetic tissues ( $\mathrm{n}=12)(32.13 \pm 18.24$ vs. $60.06 \pm 21.43$ nmol.mg $\operatorname{protein}^{-1} \cdot \mathrm{h}^{-1}, \mathrm{P}<0.05$, respectively). No differences were found for $\mathrm{V}_{\max }$ values of MAO-B between the nondiabetic $\left(15.20 \pm 3.03\right.$ nmol.mg protein $\left.{ }^{-1} \cdot h^{-1}\right)$ and the diabetic $\left(12.31 \pm 6.87 \mathrm{nmol} . \mathrm{mg}\right.$ protein $\left.{ }^{-1} \cdot \mathrm{h}^{-1}\right)$ tissues.

The SSAO $\mathrm{K}_{\mathrm{m}}$ values did not show statistical significance between the groups. The SSAO $\mathrm{V}_{\max }$ values from the diabetic tissues were significantly lower than $\mathrm{V}_{\max }$ values of the non-diabetic tissues $(148.30 \pm 39.11$ vs. $229.10 \pm 46.28$ nmol.mg $\operatorname{protein}^{-1} \cdot \mathrm{h}^{-1}, \quad \mathrm{P}<0.05$, 
respectively). No sex differences in the kinetic parameters of the three enzymes were observed.

\section{NA content}

The non-diabetic tissues had higher NA content $(0.220 \pm 0.117 \mu \mathrm{g} / \mathrm{g}$ tissue, $\mathrm{n}=12)$ than tissue from patients with type 2 diabetes $(0.065 \pm 0.059 \mu \mathrm{g} / \mathrm{g}$ tissue, $\mathrm{n}=8$, $\mathrm{P}<0.05$ ).

There was no correlation between the NA content and the donor age in the non-diabetic group (Pearson $\mathrm{r}=0.205, \mathrm{P}=0.522$ ) or the type 2 diabetic group (Pearson $\mathrm{r}=0.525, \mathrm{P}=0.181$ ).
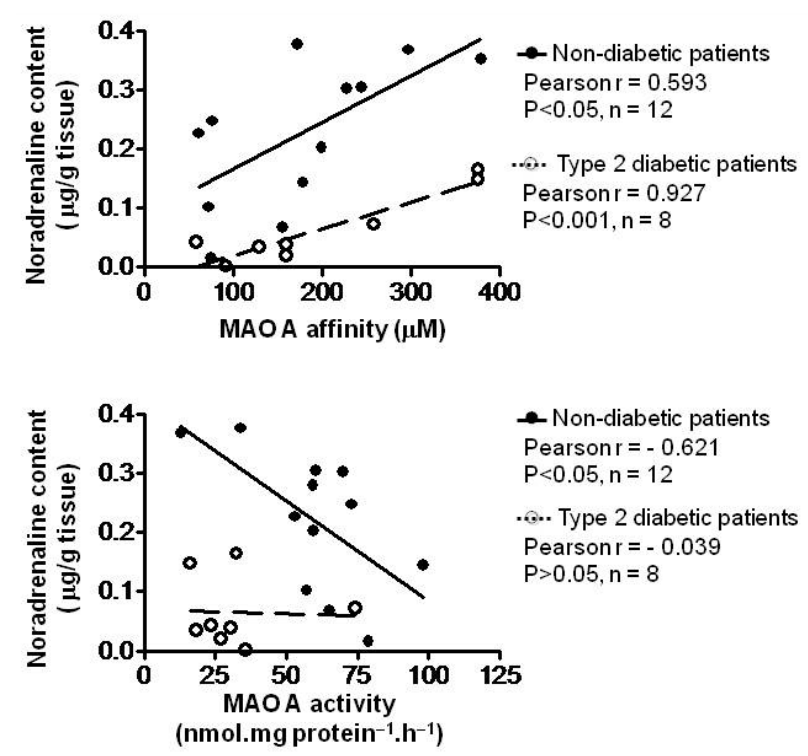

Fig. 1. Scatter plot correlations between noradrenaline content and MAO-A $\left(K_{\mathrm{m}}\right.$ or $\left.V_{\max }\right)$ for non-diabetic and type 2 diabetic groups.
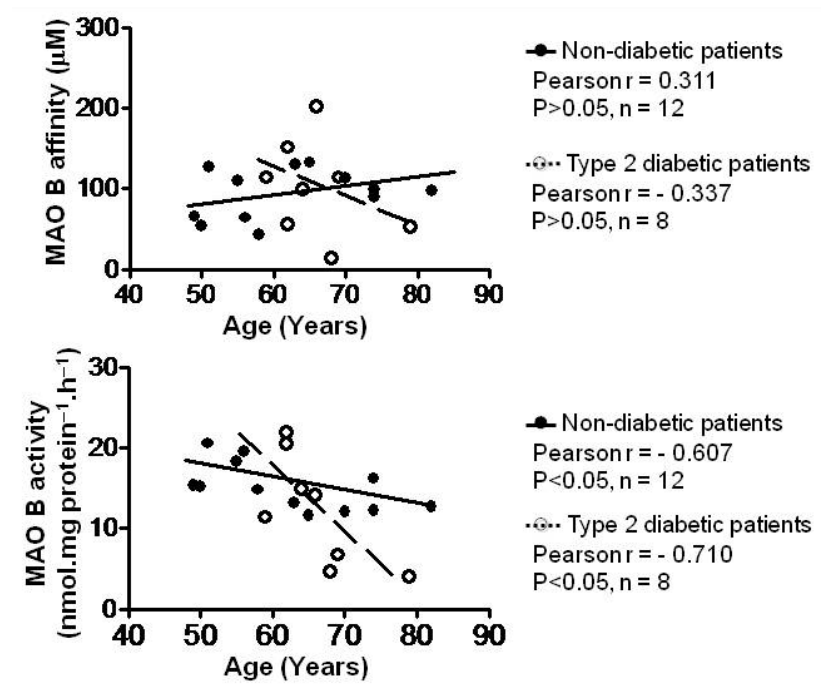

Fig. 2. Scatter plot correlations between age and MAO-B $\left(K_{\mathrm{m}}\right.$ or $\left.V_{\max }\right)$ for non-diabetic and type 2 diabetic groups.
A negative correlation was found between NA content and MAO-A $\left(\mathrm{V}_{\max }\right)$ in the non-diabetic tissue (Pearson $\mathrm{r}=-0.621, \mathrm{P}<0.05)$, while MAO-A $\left(\mathrm{K}_{\mathrm{m}}\right)$ was positively correlated with NA content for both nondiabetic tissue (Pearson $\mathrm{r}=0.593, \mathrm{P}<0.05$ ) and type 2 diabetic tissue (Pearson $\mathrm{r}=0.927, \mathrm{P}<0.01$ ), (Fig. 1). There was no correlation between MAO-A $\left(\mathrm{V}_{\max }\right.$ and $\left.\mathrm{K}_{\mathrm{m}}\right)$ and patient age in either group.

No statistical correlation between NA content and MAO-B was found for either group. The MAO-B $\left(\mathrm{V}_{\max }\right)$ was negatively correlated with patient age in the non-diabetic group (Pearson $\mathrm{r}=-0.607, \mathrm{P}<0.05$ ) and type 2 diabetic group (Pearson $\mathrm{r}=-0.710, \mathrm{P}<0.05$ ), (Fig. 2). There was no correlation between SSAO $\left(\mathrm{K}_{\mathrm{m}}\right.$ and $\left.\mathrm{V}_{\max }\right)$ and the patient age in either group.

\section{Discussion}

Oxidative stress may contribute to the development of microvascular and cardiovascular diseases in patients with diabetes (Kuroki et al. 2003). Moreover, increased levels of oxidative stress markers have always been related to cardiovascular problems, atherosclerosis or hypertension, although there are some controversies about the pathophysiological function. Recent research has been focused in those processes in order to clarify unsolved questions concerning the vascular biology of arteries and veins (Szasz et al. 2007).

The present study showed that: 1) MAO-A and SSAO activities and NA content of type 2 diabetic tissues are lower than in non-diabetic tissues, while MAO-B remained unchanged; 2) The $K_{\mathrm{m}}$ values did not show statistical significance between the groups for both MAO (type A and B) and SSAO; 3) MAO-A $\left(K_{\mathrm{m}}\right)$ showed a positive correlation with NA content in diabetic and nondiabetic tissues. There was a negative correlation between MAO-A $\left(V_{\max }\right)$ and NA content in the non-diabetic tissues, which disappears under diabetic conditions; 4) MAO-B $\left(V_{\max }\right)$ showed a negative correlation with age for tissues from both groups.

Immunohistochemical studies revealed the presence of sympathetic and sensory-motor nerves in arteries and veins obtained from human colonic specimens. The human mesenteric vessel innervation system plays a particular and important role in controlling mesenteric vein capacitance, which is reflected by their dense innervations (Birch et al. 2008).

MAO plays a role in the metabolism of biogenic amines, regulation of neurotransmitter levels and control 
of intracellular amine stores; however, in the gastrointestinal tract and circulatory system, MAO may serve a protective function by regulating dietary amines levels, which exert potent vasopressor effects (Herraiz and Chaparro 2006). Although the catalytic products from oxidative deamination of amines (hydrogen peroxide and ammonia) could exert a cytotoxic effect, the biogenic amines could be viewed as cytoprotectors and/or as toxicants. The balance between the oxidant and antioxidant enzymes appears to be very important in carcinogenesis as well as in regulation of cell growth (Pietrangeli and Mondovi 2004). Also, in an induced solid tumor breast cancer rat model, MAO-A activity increased whereas MAO-B and SSAO activities diminished with malignancy (Lizcano et al. 1991).

In rabbit femoral smooth muscle cells, tyramine degradation promoted by MAO-A activates stressinduced mitogenic signalling which could participate in excessive remodelling and alteration of the vascular wall (Coatrieux et al. 2007). MAO-A, as an intraneuronal enzyme, could participate in extraneuronal metabolism, as was suggested by the positive correlation between enzyme activity and NA content in some vascular tissues, such as human umbilical arteries, dog saphenous veins, mesenteric arteries and rabbit ear arteries (Caramona 1986). Therefore, our data concerning the MAO-A $\left(K_{\mathrm{m}}\right)$ in mesenteric arteries of diabetic and non-diabetic tissues showed a positive correlation with NA content. Furthermore, MAO-A $\left(V_{\max }\right)$ in the non-diabetic tissues was negatively correlated with NA content, the increase in MAO-A led to a decrease in NA content while in the diabetes tissues none of the correlations were found, suggesting that the terminal nerve endings are inoperative. So, in the pathogenesis of diabetes, there is a loss of NA content, a decrease of enzymatic processes and a degradation of terminal nerve endings. These data suggest that the decreases in MAO-A activity in the mesenteric arterial tissues of patients with type 2 diabetes is associated with the diabetic neurological degeneration. This possibility must be further explored, namely through immunohistochemical analysis of arteries from diabetic patients.

No statistical differences were found for MAOB $K_{\mathrm{m}}$ and $V_{\max }$ in the arterial homogenates studied, indicating that hyperglycaemia does not interfere with the mechanism of MAO-B oxidative deamination. However, the negative correlation between MAO-B $\left(V_{\max }\right)$ and the patient age in both type 2 diabetic tissues and non- diabetic tissues has demonstrated a decrease in the MAO$B$ activity in those peripheral tissues which is dependent on aging. Taken together, these results demonstrate that MAO-A and MAO-B have different roles in monoamine metabolism in inferior mesenteric arteries.

The degradation of adrenaline by MAO-A produces methylamine and SSAO catalyzes the metabolism of methylamine to formaldehyde. Endothelial cells are quite sensitive to formaldehyde and may be involved in the endothelial injury (Yu et al. 1997). The formaldehyde may also be involved in protein structure alteration, which causes protein deposition associated with chronic pathological disorders such as diabetic complications, atherosclerosis and Alzheimer's disease (Gubisne-Haberle et al. 2004).

We and other have previously reported serum or plasma SSAO activity increases in type 2 diabetic patients (Mészáros et al. 1999, Gokturk et al. 2003, Obata 2006, Nunes et al. 2010), which might be caused by translocation of SSAO from the tissue-bound to plasma due to changes in arterial permeability. These results are in agreement with another study which proposed that soluble SSAO is derived from the membrane-bound enzyme ( $\mathrm{Yu}$ et al. 1994). Our findings in homogenates of inferior mesenteric arteries from patients with type 2 diabetes showed a low SSAO activity when compared with the non-diabetic arteries and no correlation with the patient age.

In conclusion, we found a decrease in NA content in diabetic arteries, possibly due to damage in the arterial walls. The reported data show that the low activity of MAO-A and SSAO in inferior mesenteric arteries of patients with type 2 diabetes is associated with several vascular changes, suggesting that MAO-A and SSAO play a role in blood vessels and hence in the pathogenesis of diabetes. These studies could open new perspectives to MAO-A and SSAO as pharmacological tools for diabetes management in order to improve the life quality of patients with type 2 diabetes.

\section{Conflict of Interest}

There is no conflict of interest.

\section{Acknowledgements}

This work was include in Centre for Pharmaceutical Studies-CEF research group and was supported by the Portuguese Foundation for Science and Technology-FCT (SFRH/BD/2005) - Portugal. 


\section{References}

BIANCHI P, KUNDUZOVA O, MASINI E, CAMBON C, BANI D, RAIMONDI L, SEGUELAS MH, NISTRI S, COLUCCI W, LEDUCQ N, PARINI A: Oxidative stress by monoamine oxidase mediates receptorindependent cardiomyocyte apoptosis by serotonin and postischemic myocardial injury. Circulation 112: 32973305, 2005.

BILLETT EE: Monoamine oxidase (MAO) in human peripheral tissues. Neurotoxicology 25: 139-148, 2004.

BIRCH DJ, TURMAINE M, BOULOS PB, BURNSTOCK G: Sympathetic innervation of human mesenteric artery and vein. $J$ Vasc Res 45: 323-332, 2008.

BOUR S, CASPAR-BAUGUIL S, IFFIÚ-SOLTÉSZ Z, NIBBELINK M, COUSIN B, MIILUNIEMI M, SALMI M, STOLEN C, JALKANEN S, CASTEILLA L, PÉNICAUD L, VALET P, CARPÉNÉ C: Semicarbazidesensitive amine oxidase/vascular adhesion protein-1 deficiency reduces leukocyte infiltration into adipose tissue and favors fat deposition. Am J Pathol 174: 1075-1083, 2009.

CARAMONA MM: Localization of monoamine oxidase of type A and B in blood vessels with different innervation patterns. Naunyn Schmiedebergs Arch Pharmacol 324: 185-189, 1983.

COATRIEUX C, SANSON M, NEGRE-SALVAYRE A, PARINI A, HANNUN Y, ITOHARA S, SALVAYRE R, AUGE N: MAO-A-induced mitogenic signaling is mediated by reactive oxygen species, MMP-2, and the sphingolipid pathway. Free Radic Biol Med 43: 80-89, 2007.

DEL MAR HERNANDEZ M, ESTEBAN M, SZABO P, BOADA M, UNZETA M: Human plasma semicarbazide sensitive amine oxidase (SSAO), beta-amyloid protein and aging. Neurosci Lett 384: 183-187, 2005.

ELLIOTT J, CALLINGHAM BA, SHARMAN DF: Semicarbazide-sensitive amine oxidase (SSAO) of the rat aorta. Interactions with some naturally occurring amines and their structural analogues. Biochem Pharmacol 38: 1507-1515, 1989.

FIGUEIREDO IV, MARTINEZ COSCOLLA A, COTRIM MD, CARAMONA MM, CALLINGHAM BA: Monoamine oxidase activities in human cystic and colonic arteries - influence of age. J Neural Transm Suppl 52: 217-223, 1998.

GOKTURK C, GARPENSTRAND H, NILSSON J, NORDQUIST J, ORELAND L, FORSBERG-NILSSON K: Studies on semicarbazide-sensitive amine oxidase in patients with diabetes mellitus and in transgenic mice. Biochim Biophys Acta 1647: 88-91, 2003.

GUBISNE-HABERLE D, HILL W, KAZACHKOV M, RICHARDSON JS, YU PH: Protein cross-linkage induced by formaldehyde derived from semicarbazide-sensitive amine oxidase-mediated deamination of methylamine. J Pharmacol Exp Ther 310: 1125-1132, 2004.

HERRAIZ T, CHAPARRO C: Analysis of monoamine oxidase enzymatic activity by reversed-phase high performance liquid chromatography and inhibition by beta-carboline alkaloids occurring in foods and plants. $J$ Chromatogr A 1120: 237-243, 2006.

KUROKI T, ISSHIKI K, KING GL: Oxidative stress: the lead or supporting actor in the pathogenesis of diabetic complications. J Am Soc Nephrol 14 (Suppl 3): S216-S220, 2003.

LIZCANO JM, ESCRICH E, RIBALTA T, MUNTANÉ J, UNZETA M: Amine oxidase activities in rat breast cancer induced experimentally with 7,12-dimethylbenz(alpha)anthracene. Biochem Pharmacol 42: 263-269, 1991.

LOWRY OH, ROSEBROUGH NJ, FARR AL, RANDALL RJ: Protein measurement with the Folin phenol reagent. J Biol Chem 193: 265-275, 1951.

MÉSZÁROS Z, SZOMBATHY T, RAIMONDI L, KARÁDI I, ROMICS L, MAGYAR K: Elevated serum semicarbazide-sensitive amine oxidase activity in non-insulin-dependent diabetes mellitus: correlation with body mass index and serum triglyceride. Metabolism 48: 113-117, 1999.

NAGATSU T: Progress in monoamine oxidase (MAO) research in relation to genetic engineering. Neurotoxicology 25: 11-20, 2004.

NUNES SF, FIGUEIREDO IV, PEREIRA JS, SOARES PJ, CARAMONA MM, CALLINGHAM B: Changes in the activities of semicarbazide-sensitive amine oxidase in inferior mesenteric artery segments and in serum of type 2 diabetic patients. Acta Diabetol 47: 179-182, 2010.

OBATA T: Diabetes and semicarbazide-sensitive amine oxidase (SSAO) activity: A review. Life Sci 79: 417-422, 2006. 
PIETRANGELI P, MONDOVI B: Amine oxidases and tumors. Neurotoxicology 25: 317-324, 2004.

RAMAKRISHNA V, JAILKHANI R: Evaluation of oxidative stress in insulin dependent diabetes mellitus (IDDM) patients. Acta Diabetol 45: 41-44, 2008.

REIS F, ROCHA L, PONTE L, ALCOBIA T, ALMEIDA L, COSTA-ALMEIDA C, TEIXEIRA F: Effect of preventive and regressive isosorbide 5-mononitrate treatment on catecholamine levels in plasma, platelets, adrenals, left ventricle and aorta in cyclosporin A-induced hypertensive rats. Life Sci 77: 2514-2528, 2005.

SZASZ T, THAKALI K, FINK GD, WATTS SW: A comparison of arteries and veins in oxidative stress: producers, destroyers, function, and disease. Exp Biol Med 232: 27-37, 2007.

YU PH, ZUO DM, DAVIS BA: Characterization of human serum and umbilical artery semicarbazide-sensitive amine oxidase (SSAO) Species heterogeneity and stereoisomeric specificity. Biochem Pharmacol 47: 1055-1059, 1994.

YU PH, LAI CT, ZUO DM: Formation of formaldehyde from adrenaline in vivo; a potential risk factor for stressrelated angiopathy. Neurochem Res 22: 615-620, 1997. 